Occasional Paper

OP no 07/6

MigIESE

October, 2006

University of Navarra

\title{
PROFITABLE BUSINESS MODELS AND MARKET CREATION IN THE CONTEXT OF DEEP POVERTY: A STRATEGY VIEW
}

\author{
Christian Seelos \\ Johanna Mair
}

IESE Occasional Papers seek to present topics of general interest to a wide audience.

IESE Business School - University of Navarra

Avda. Pearson, 21 - 08034 Barcelona, Spain. Tel.: (+34) 932534200 Fax: (+34) 932534343

Camino del Cerro del Águila, 3 (Ctra. de Castilla, km 5,180) - 28023 Madrid, Spain. Tel.: (+34) 913570809 Fax: (+34) 913572913

Copyright @2006 IESE Business School. 


\title{
PROFITABLE BUSINESS MODELS AND MARKET CREATION IN THE CONTEXT OF DEEP POVERTY: A STRATEGIC VIEW
}

\author{
Christina Seelos* \\ Johanna Mair **
}

\begin{abstract}
Framing the entry into underdeveloped countries as a business opportunity is conceptually appealing. While previous work on strategies to pursue the bottom level of the global income pyramid has shifted paradigms about poverty, the focus in this paper is to move on from the "whether to do it" question to contribute to a better understanding of "how to do it" from the perspectives of corporate and competitive strategy. Using three cases, two from Bangladesh and one from India, insights are generated into how business models can be structured and executed to generate the necessary profits for companies to justify investments into market entry and market building, while at the same time integrating and serving the poorest and their unique needs as well. The authors explicitly focus on how to recognize, access and configure resources that local pioneers have already built in extremely poor countries. The aim of this paper is not to develop prescriptions, but to generate ideas about the opportunities available to companies working in tandem with local entrepreneurial organizations to build business models that are able to achieve multiple strategic objectives concomitantly.
\end{abstract}

\footnotetext{
* Visiting Lecturer, IESE

** Professor of General Management, IESE
}

Keywords: business models, poverty alleviation, market creation. 


\section{PROFITABLE BUSINESS MODELS AND MARKET CREATION IN THE CONTEXT OF DEEP POVERTY: A STRATEGIC VIEW}

\section{Introduction}

Resources and capabilities are considered essential building blocks for corporate and competitive strategy (Barney, 1995; Teece et al., 1997). They are built through competition over how to best serve customer needs and are selected for propensities that bestow an advantage on individual companies. Research has also furthered our understanding of how to leverage existing resources and capabilities and how to access those of local companies in order to enter less- developed or emerging markets (Hitt et al., 2000; Tallman and Fladmoe-Lindquist, 2002). Sometimes, however, recognizing the opportunities for growth and new wealth creation seems easier than discovering how best to exploit them and determining whether existing resources and capabilities indeed facilitate such exploitation (London and Hart, 2004; Wright et al., 2005).

An extreme case of this dilemma exists in the form of the least-developed countries, where mass poverty means that even the most basic needs of millions of people are not met and markets to serve them are largely absent. This provides a bizarre contrast to the mature markets in highly developed countries, where competition tends to optimize price/benefit ratios for the consumer and thus enables people to consume more of the things they want and not just what they need to survive - an important driver of choice and perceived quality of life. Therefore, in the context of deep poverty - by which we mean countries with very low economic wealth creation and significant clusters of people living below recognized poverty lines, such as daily incomes of less than two US dollars - companies face a triple dilemma:

First, there may in fact be no markets that a company can enter and an entry decision might thus revolve more around how to build markets than to enter them; second, doing it alone might not be feasible, given that company resources and capabilities have evolved in a very different environment and may only be partly relevant to a poor-country context; and third, the absence of markets translates into a lack of local companies with which it would be feasible to form the kind of partnerships that might be needed to provide the locally relevant resources and capabilities mentioned above. 


\section{"Whether" or "how" to enter underdeveloped markets?}

Previous work on strategies to pursue business opportunities at the bottom of the income pyramid has certainly helped to shift paradigms about poverty (Prahalad and Hart, 2002). The debate around the idea of viewing the poor as customers and not merely the recipients of donations has been intriguing, but we still lack models for companies to realize this vision. In the next 40 years, it is expected that 2.2 billion more people will inhabit this planet, but only 0.026 billion of them will live in high-income countries (The World Bank, 2006). These people will therefore have significantly lower purchasing power and many will not be accessible through traditional corporate channels. Two questions lie at the heart of evaluating the attractiveness of doing business in underdeveloped markets: First, whether to do it; and second, how to do it.

The main arguments for why executives should care about underdeveloped markets are well established and have been repeatedly communicated (Prahalad and Hammond, 2002; Seelos and Mair, 2005a). The declining growth and fast commoditization of existing markets puts a strain on managerial decisions and has contributed to a focus on value appropriation at the cost of concentrating on new ways to create value. Cost cutting, reorganizations and layoffs aim to increase efficiencies and productivity, but may also limit creativity and innovativeness. Among the many concepts and ideas on how to escape from the pressures caused by hypercompetition and lack of growth is the "Innovator's Solution" put forward by Christensen and Raynor (2003). They argue that managers should forgo the obsession with existing customers and markets that are "core" to a company's business and instead consider low-end disruptions that create products and services at radically new quality/price relations to satisfy a customer need. This could well be an ideal framework for looking at poor countries, where innovation and low-end disruption might be the only ways to serve customers (Hart and Christensen, 2002). Kim and Mauborgne (2004) suggest creating and occupying new market space through value innovation, understood as a new combination of elements of customer benefit into a single offering. The absence of markets for many goods and, indeed, of whole industries in underdeveloped countries might be the ultimate opportunity for creating market space. However, while these concepts sound compelling in theory, finding ways to enact them determines success and failure.

The big question therefore is: how can companies create and occupy new market space in the context of deep poverty? In fact, at least partial answers to the question of "how" to do this may be prerequisites to answering the question of "whether" to do it. A complex set of factors might explain the lack of corporate action in the context of mass poverty, including the extent of a supportive institutional landscape, levels of political and economic uncertainties, lack of channels to effectively access the poor, and many others. Furthermore, resources and capabilities that companies have developed in mature markets may be of low or uncertain value in the context of poor countries. It is often unclear which resources and capabilities are necessary to successfully act in such a context and it could be difficult and might take a very long time to build them. In this paper we hope to contribute to a better understanding of how companies might be able to recognize and access the relevant resources and capabilities that entrepreneurial pioneers have already built instead of building them from scratch. Most importantly, we give three examples of how resources and capabilities contributed by both the companies and the local pioneers can be configured into novel business models that satisfy both the needs of the poor and the needs of the company for adequate economic returns. Furthermore, we highlight the observation that these business models comprise different organizational structures, each pursuing their own strategic objectives. 


\section{Entrepreneurs provide important resources and capabilities}

This paper builds on a three-year research project that investigated the work of entrepreneurs who had succeeded in building business models in underdeveloped countries that effectively served the poor (Seelos and Mair, 2005b). The sample focused on entrepreneurs who had successfully acted in a context lacking supportive institutions, both political and economic. An inchoate institutional landscape translates into a lack of social welfare and risk management systems, and an absence of markets in which entrepreneurs and companies can compete as to how to best serve people's needs. As North (1990) pointed out: "Third World countries are poor because the institutional constraints define a set of payoffs to political/economic activity that do not encourage productive activity". The inability of the poorest to either create or respond to economic opportunities is believed to sustain mass poverty in these contexts (Abramovitz, 1986). Therefore, the beneficial social impact of even individual entrepreneurs can be significant in the context of deep poverty.

The strategic objectives of entrepreneurs operating at the base of the economic pyramid frequently consist of directly creating positive social outcomes such as "treating as many poor patients as possible", "providing financial support to the poorest people", or "creating as many jobs as possible". Recently, these entrepreneurs have been labelled "social entrepreneurs". For the purpose of this paper we use the terms "social entrepreneurs" and "entrepreneurs" interchangeably.

Acting below the competitive radar screen of companies, these entrepreneurs build resources and capabilities to achieve a blend of social and economic objectives. As we argue in this paper, such resources and capabilities are therefore very relevant to the local context and are often undervalued from an economic perspective, which gives them potentially strategic importance for companies that consider building a presence in those countries where such entrepreneurs operate. In catering to the most basic human needs, profits are often a counterintuitive outcome, particularly when judging the underlying "business case" from the traditional paradigms of corporate and competitive strategies. For example, a long-held myth of the banking industry was that it was not feasible to make money through the provision of micro-loans to the poor. The Grameen Bank and other pioneers of microfinance have proven this assessment wrong. Along the way, these pioneers have built capabilities that allow them to profitably serve the poor. The Grameen Bank has built a network of 70 million members or customers in more than 60,000 villages across Bangladesh. The ongoing social and economic development throughout this network translates into huge market potential. Grameen Bank, building on its capabilities to organize and work with the poor, has also built a diverse range of other commercial entities. It has created whole new markets in the primary and secondary sectors but increasingly in the tertiary sector as well. The ability of Grameen management to study and evaluate the socio-economic impacts of its actions translates into an important organizational capability to allocate resources for scaling up successful prototypes and weeding out those that do not work. Accessing these resources and capabilities could form an important base for companies to build up business models that reach a suitable scale and generate the necessary profit levels to justify their investments. The first case detailed in this article will provide a taste of the opportunity space that we propose. ${ }^{1}$

\footnotetext{
${ }^{1}$ This information is derived from interviews by the authors with managers from Grameen Bank, GrameenTelecom, Grameen Phone and Telenor in 2005, as well as secondary information from various sources.
} 


\section{Case 1. Grameen Phone and Telenor: the symbiosis of economic and social objectives structures a new business model}

During the 1990s Telenor, the incumbent Norwegian telecommunications company, faced the challenge of saturation in its home markets. State-owned and relatively small, it did not feel ready to go after emerging growth markets like China or India, and when the CEO of Telenor received a call from a friend - the A mbassador of Bangladesh - asking him to consider building a market for mobile phones in that country, his initial reactions were mixed at best. He could not have known then that Bangladesh, a country known for its overpopulation, extreme poverty, political instability and corruption, would become one of Telenor's most profitable growth markets. What eventually made Telenor's CEO decide in favor of the joint venture was the excellent reputation of the local partner in Bangladesh: the Grameen Bank, founded in 1976 by Professor Muhammad Yunus, who is today one of the world's most prominent social entrepreneurs. The joint venture led to the formation of two separate organizations: one aimed at building a purely commercial model, GrameenPhone; and one with a mission to cater to the poorest by teaching them to use phones for entrepreneurial purposes, GrameenTelecom (Malaviya et al., 2004).

When it started out in 1997, GrameenPhone was one of four companies to receive a license to operate a mobile network in Bangladesh. It became profitable in 2000, and passed two million subscribers in late 2004 and 6 million in February of 2006. GrameenPhone is now one of the largest private companies in Bangladesh and the second largest taxpayer, which reflects the attractive profit margins of the business. In 2006 it had a market share of 60 percent. $^{2}$ Singledigit market penetration in a country of 150 million people signifies the potential for further growth. Meanwhile, GrameenTelecom, the non-commercial arm of the joint venture, created more than 100,000 jobs for microentrepreneurs they called "Village Phone Ladies" - these were poor women who, despite being illiterate, quickly learned how to operate a mobile phone and generate income from it. They provide higher in-demand phone services in previously unconnected villages that allow people to contact relatives abroad, facilitate repatriation payments, save on costly trips for administrative purposes and other issues to Dhaka, the capital, and provide many other advantages. The social and economic value created from this market innovation at the lowest rungs of the world's income ladder is enormous. GrameenTelecom is also profitable and accounts for more than $10 \%$ of the revenues of GrameenPhone.

The following paragraphs list some of the important resources and capabilities that Telenor could access through the collaboration with Grameen Bank. We also highlight some of the synergies that were created by the collaboration and discuss the strategic decision to keep two separate organizational structures.

\footnotetext{
${ }^{2}$ Source: Telenor Group, financial data, fourth quarter 2005, www.telenor.com.
} 


\section{Intangible resources}

Mr. Yunus was considered a person of impeccable integrity - probably an ideal partner in Bangladesh, where it is still hard to find influential partners that are resistant to corruption. Yunus had already demonstrated the financial viability and potential for socio-economic development of a business model that the banking sector deemed unfeasible: microcredit, which is today a global industry. That kind of credibility is a scarce asset and extremely valuable in a poor-country context. The brand that Grameen Bank had built was an invaluable resource for Telenor. In fact, using the name GrameenPhone for the commercial part of the venture was considered a crucial success factor, leveraging trust and justifying a license to operate not only with the government, but also with potential customers, the rural poor and the urban middle class.

\section{Tangible resources}

Valuable technology resources can often be accessed relatively cheaply in developing countries. They constitute remnants of the billions in development funds that were poured into poor countries for decades in the hope of kick-starting economic growth. In Bangladesh, the Norwegian Agency for Development (NORAD) had invested in a fiber-optic network for the internal communication of the national railway system that was nowhere near being used to its full capacity. Thus, Telenor was able to acquire an important asset cheaply.

Because the venture had two "arms" - one aimed at a commercial market and the other at social development - Telenor also had access to very favorable funding provided by the Asian Development Bank, the IFC, the Commonwealth Development Corporation and NORAD. This effectively lowered the cost of capital for the company and, as a result, until the first quarter of 2005, overall capital expenditures for Telenor are estimated at a mere 600 million USD. This translates into about 100 USD per customer; far less than the net present value of expected future cash flows even at a high cost of capital to reflect the risk of the venture.

\section{Capabilities}

Over decades, Grameen Bank had developed special skills in accessing, communicating and working with the rural poor in more than 50,000 villages throughout Bangladesh. This created the opportunity and know-how for integrating a vastly untapped potential market into the overall business model which now drives significant revenue to GrameenPhone. Deep expertise in providing loans and ensuring the accountability of individual members of the network enabled Grameen to select appropriate phone owners, efficiently collect payments and resolve any problems that might crop up in the rural villages.

The art of setting up a successfully functioning microfinance system had been mastered by Grameen Bank and enabled poor people to convert future earnings from selling mobile communications into current financial value. Thus, there was no need to rely on donations of mobile phones to the rural poor for the GrameenTelecom part of the venture to succeed. Instead, having them pay through the provision of loans instilled discipline and commitment and was the foundation of a profitable business model for all parties involved. The group-based social mechanisms established by Grameen Bank that supported people to repay loans were directly applicable to the phone model as well. 


\section{Synergies}

Mobile communication services are considered a powerful driver of development that go hand in hand with increased incomes. ${ }^{3}$ In the case of Telenor's joint venture, a positive feedback loop is created by serving the rural poor through GrameenTelecom that seems to build up the size of the middle class, the main target for GrameenPhone over time. As the former CEO of Telenor used to say: "Good business is good development and good development is good business".

The fact that GrameenTelecom aimed to serve the rural areas in Bangladesh made building countrywide coverage a prime objective. This was considered an important driver of customer satisfaction, increasing customers' willingness to pay, both for the commercial arm and the non-commercial arm of the business, as reflected in today's 60 percent market share.

The strategic value of these resources and capabilities also derives from the fact that they are very difficult to imitate because of the time it takes to build them. Furthermore, they are also scarce, mostly because there is no efficient market that incentivizes people to invest in creating them. In a sense, Telenor was able to preempt access to these scarce resources, thus building strong hurdles for imitation by competitors. The other three private companies that received mobile licenses in Bangladesh at the same time as Telenor were much less successful and failed to build a dominating market share; the second largest provider, AKTel, had 28 percent of the market in 2005. Telenor's profitability and the growth prospects in Bangladesh have recently attracted market entry by other international players such as Telekom Malaysia and Orascom.

\section{Case 2. Map Agro and Waste Concern: A business model based on complementary resources and capabilities}

A second collaborative model demonstrates how the resources of companies and social entrepreneurs can complement each other to enable a different type of value chain that creates a new and very profitable market for the company partner. This is another case from Bangladesh reflecting insights from a recent field trip by the authors rather than a pattern unique to Bangladesh (Thurner et al., 2006). ${ }^{4}$ One side effect of emerging economic growth is the generation of waste in many forms. In Dhaka, the capital of Bangladesh, which has a population of around 11.3 million, about 4,000 tonnes of waste is produced daily, mainly as byproducts of consumption and various other economic activities. Two reinforcing paradigms have, until recently, prevented effective waste treatment in Bangladesh. Firstly, the private sector failed to see how waste could be exploited for economic gain without significant investment and sophisticated technology. Secondly, the public sector therefore believed that it had to deal with the problem through centrally managed processes. However, despite spending 50 percent of its total annual budget on waste removal, the Dhaka City Council (DCC) could only deal with less than 40 percent of the waste created. As a result, waste piled up in the streets and in landfill sites, creating a huge number of serious social threats, including many diseases, insufferable odor, leakage of pollutants into water sources, methane gas, and exposing "waste-pickers", who were usually women and children, to toxic and otherwise hazardous substances. In early 1994, two entrepreneurs, Maqsood Sinha and Iftekhar Enayetullah,

\footnotetext{
${ }^{3}$ For example, see: "Africa: The impact of mobile phones", in "The Vodafone Policy Paper Series", Number 2, March 2005.

${ }^{4}$ This information is derived from interviews by the authors with managers from Waste Concern in 2005 and 2006, as well as secondary information from various sources.
} 
launched Waste Concern, based on a simple idea: turn waste into compost and sell this as a valuable substitute to chemical fertilizers. Every year, four million tonnes of chemical fertilizers were produced in Bangladesh, responding to the pressure to feed a burgeoning population made up mostly of people living in poverty. Despite the fact that overuse of chemical fertilizers drastically lowered soil quality, farmers had no real choice because, at the time, there was no commercial market for substitutes. Waste Concern's model integrated a community-based house-to-house collection system for waste, composting and ultimately marketing and selling the compost as fertilizer. Initially, Waste Concern sold its product to the usual small markets for compost: home gardeners and small organic farmers. However, measurable elimination of the waste-problem required access to much larger markets in order to create a pull for building supply-side scale and cost efficiency.

Approaching the largest fertilizer company, Map Agro, initially failed, but repeated attempts to convince the CEO resulted in a "trial contract" that guaranteed annual sales of 200 tonnes of compost. When positive feedback and demand from farmers increased, Map Agro invested in a purpose-built enrichment factory and started selling ground pure and nutrient-enriched organic compost on a larger scale with current sales of about 50,000 tonnes per year. The final product was distributed throughout Bangladesh using the extensive dealer network of Map Agro's parent company, Alpha Agro Ltd., a fertilizer trading company. The financials for Map Agro are attractive. It buys compost at 2,500 Taka per tonne (each unit of compost reflecting 4 units of processed waste or 625 Taka per tonne of waste), and sells pure compost for 6,000 Taka per tonne and enriched compost for 12,000 Taka per tonne (reflecting 1,500 and 3,000 Taka per tonne of waste, respectively). The economic value created in this model compares favourably to the cost of roughly 2,000 Taka per tonne of waste treated by the old DCC process as shown in Figure 1.

\section{Figure 1}

Comparison of economic value destroyed (old centralized waste management process) or created through a new private- sector value chain

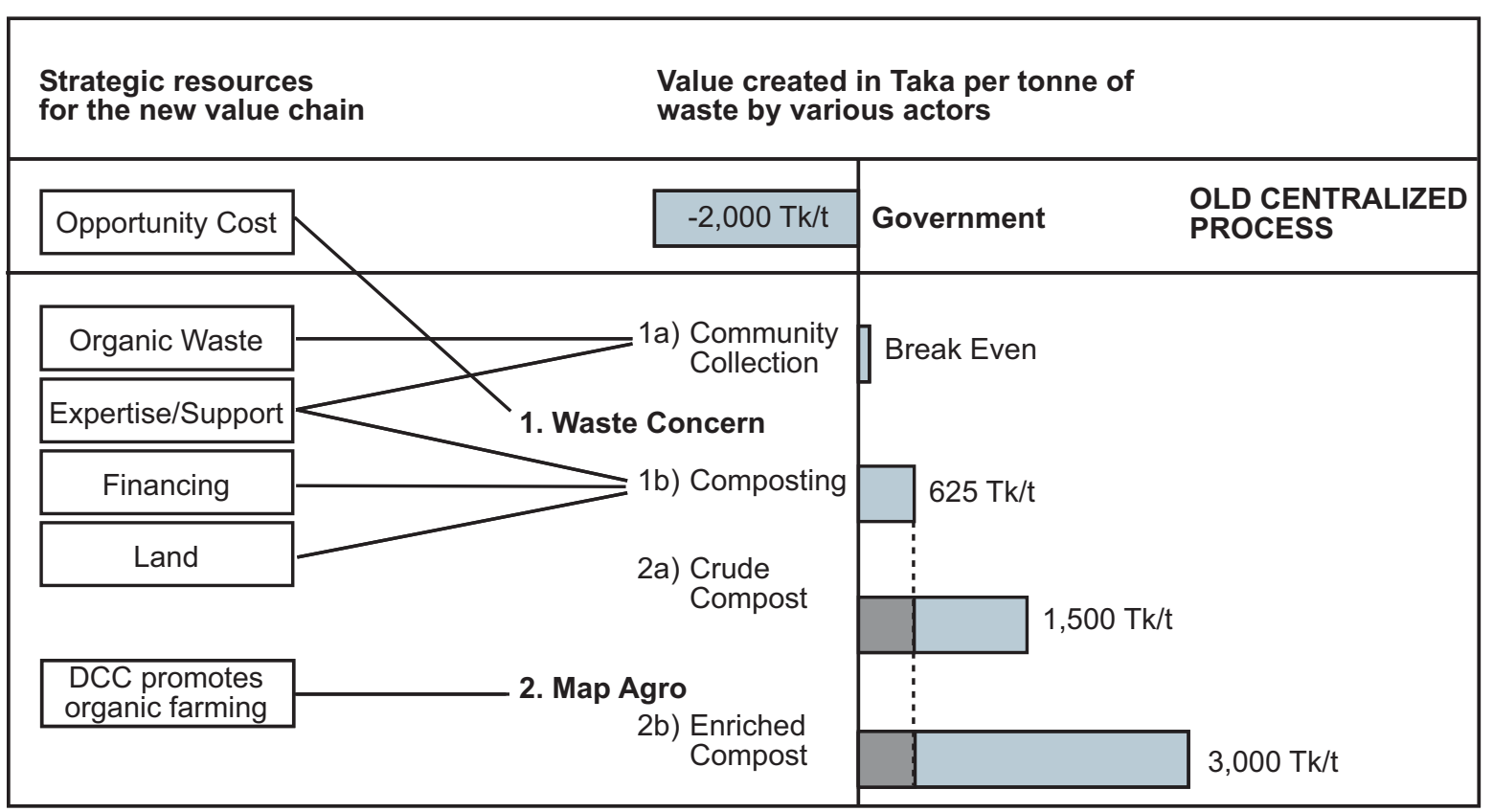


The new value chain, extending from waste produced in urban areas to selling compost to rural farmers, created a number of new jobs for the poorest at the community level and lowered their exposure to health threats. This enabled Waste Concern to obtain important strategic resources, including funding and technical expertise and support from international organizations for both the pilot phases and for scaling up the numbers and capacities of its composting plants. Waste Concern helped the government to deal with a seemingly insurmountable social problem and in return, the land for housing the compost plants was donated by the government; an important cost driver for the project. Through collaboration with Waste Concern, the private sector in the form of Map Agro was able to access a product for which the cost did not fully reflect its economic value. It could thus build a new and very profitable market space for chemical fertilizer substitutes. The profits generated for the private-sector partner in this case, motivated the entry of other companies competing with Map Agro for their exclusive relationship with Waste Concern. Waste Concern is currently evaluating its potential collaboration with three other fertilizer companies to bring its compost product to the market. How can Map Agro leverage its existing relationship with Waste Concern to prevent this? One way would be to use traditional strategic maneuvers such as investing in enough capacity to provide a disincentive to the entry of competitors. Another way could be to transform the current arm's-length relationship with Waste Concern to a real value-added relationship where joint activities and shared social objectives could build the trust and benefits necessary to overcome the reservations Waste Concern might have over a monopoly provider for its product.

\section{Case 3. Aurolab and Aravind: an integrated business model that exemplifies a potentially disruptive strategy}

David Green founded Aurolab in India as a non-profit organization in 1992 in order to redesign the production process of high-quality intra-ocular lenses used in eye surgery for which there is a demand of about 200 million visually impaired people worldwide (Mair and Cordes, 2004). Most of the potential patients live in low-income countries and the main suppliers are not willing to sell their products at the prices that the poor are able to pay. When Aurolab started, the industry was concentrated and dominated by a few players. The low price sensitivity of wealthy customers and the insurance system that was clouding the real price from patients, allowed the manufacturers to enjoy huge margins. A local non-profit hospital, the A ravind Eye Hospital, located in a very poor region of India, was desperate to overcome the most important hurdle to its mission of providing eye surgery to poor people: the steep prices for intra-ocular lenses charged by the existing manufacturing companies. Green built a state-of-the-art production facility named Aurolab next door to Aravind and integrated it with the patient care model of the hospital. Today, the group of Aravind Eye Hospitals screens over one million patients a year and performs several hundred thousand eye surgeries. The overall strategy that both entities employ is "maximizing the number of people served". In this model, the poorest patients pay nothing (they account for 50 percent of surgeries), however 35 percent pay well above cost and the overall business model generates a net profit margin of 60 percent. The enormous profit margin is clearly counterintuitive but now drives fast global expansion. Aurolab is already among the largest suppliers of lenses in the global market, with a share of more than 10 percent. Table 1 illustrates how the integrated business model of Aurolab and A ravind achieved strategic objectives with a consistent set of activities. 


\section{Table 1}

How strategic objectives relate to sets of activities in the Aurolab - Aravind business model

\begin{tabular}{|l|l|}
\hline Strategic Objectives & \multicolumn{1}{|c|}{ Activities } \\
\hline $\begin{array}{l}\text { LARGE SCALE } \\
\text { (treat as many people as } \\
\text { possible) }\end{array}$ & $\begin{array}{l}\text { Collaboration with strategic partner Aravind hospital to ensure demand; } \\
\text { access to rural areas through NGO community partners; regular eye } \\
\text { camps; 3 times more surgeries per doctor than in the US; profits used to } \\
\text { expand capacity. }\end{array}$ \\
\hline $\begin{array}{l}\text { HIGH QUALITY } \\
\text { (do not let poverty compromise } \\
\text { the quality of treatment offered) }\end{array}$ & $\begin{array}{l}\text { Building a quality-focused culture from the beginning; accessing highly } \\
\text { qualified doctors from top institutions; quality is restricted to where it } \\
\text { matters, i.e. the treatment itself; steep learning curve through focused job } \\
\text { designs (doctors perform only surgeries). }\end{array}$ \\
\hline $\begin{array}{l}\text { FREE SURGERY } \\
\text { (do not deny the poor access to } \\
\text { treatment) }\end{array}$ & $\begin{array}{l}\text { Achieve an average price that reflects local ability to pay through what } \\
\text { we call "social target costing"; placing Aurolab factory in low-cost } \\
\text { country; getting start-up grant; achieving scale quickly; working with } \\
\text { NGO partners to avoid marketing costs; efficient operations } \\
\text { management; status as training institution saves labor costs; half of the } \\
\text { patients are unable to pay anything but get the same quality treatment; } \\
\text { they are mass supplied using very low-cost facilities and efficient self- } \\
\text { selection mechanisms. }\end{array}$ \\
\hline $\begin{array}{l}\text { FINANCIALLY VIABLE } \\
\text { (create and explore } \\
\text { opportunities for earned income) }\end{array}$ & $\begin{array}{l}\text { One third of patients pay well above costs; they value the high-quality } \\
\text { treatment like everyone else but are willing to pay for access to much } \\
\text { nicer facilities; 10\% market share globally creates good margins given } \\
\text { the very different price/cost ratio achievable in this model. }\end{array}$ \\
\hline
\end{tabular}

The activities and objectives in this strategy are mutually reinforcing to create a consistent business model. The objective to provide free surgery helps to achieve scale very quickly and also helps to access community partners as a valuable "low cost" resource. Scale, along with a diversity of interesting patient cases, makes Aravind an attractive training center that receives top doctors from all over the world at very low labor costs. Furthermore, scale enabled both Aurolab and the doctors to drive down a learning curve extremely fast. This has had positive effects on both the cost and the quality dimensions of the business model. The free surgery aspect is made very cost-efficient by providing only very basic facilities that enact a process of social self-selection and create an effective hurdle for those who can afford to pay to demand free treatment. For example, wealthier people in India do not want to sit in the same waiting room as the very poor. Furthermore, the reputation for quality also drives the demand of patients coming from richer countries with much greater willingness to pay. This partially sustains the significant profit levels attainable in this model. The other potential source of profits which has not yet been fully exploited is that Green had ensured that the high quality of the A urolab lenses achieved the necessary certification for sales in the EU and US, which would net much higher market prices. This feature of the business model could be a strong competitive threat to incumbent manufacturers if Aurolab chose to exploit it. At the moment, however, both Aurolab and Aravind's strategic objective remains the maximization of numbers of people treated and not maximizing profits. To understand and visualize the links and interdependencies of activities and multiple objectives, and how this creates a consistent overall business model, we have produced a high-level strategy model as shown in Figure 2. 


\section{Figure 2}

The resources and capabilities of Aravind Eye Hospital and Aurolab Factory are fully integrated to create an innovative business model

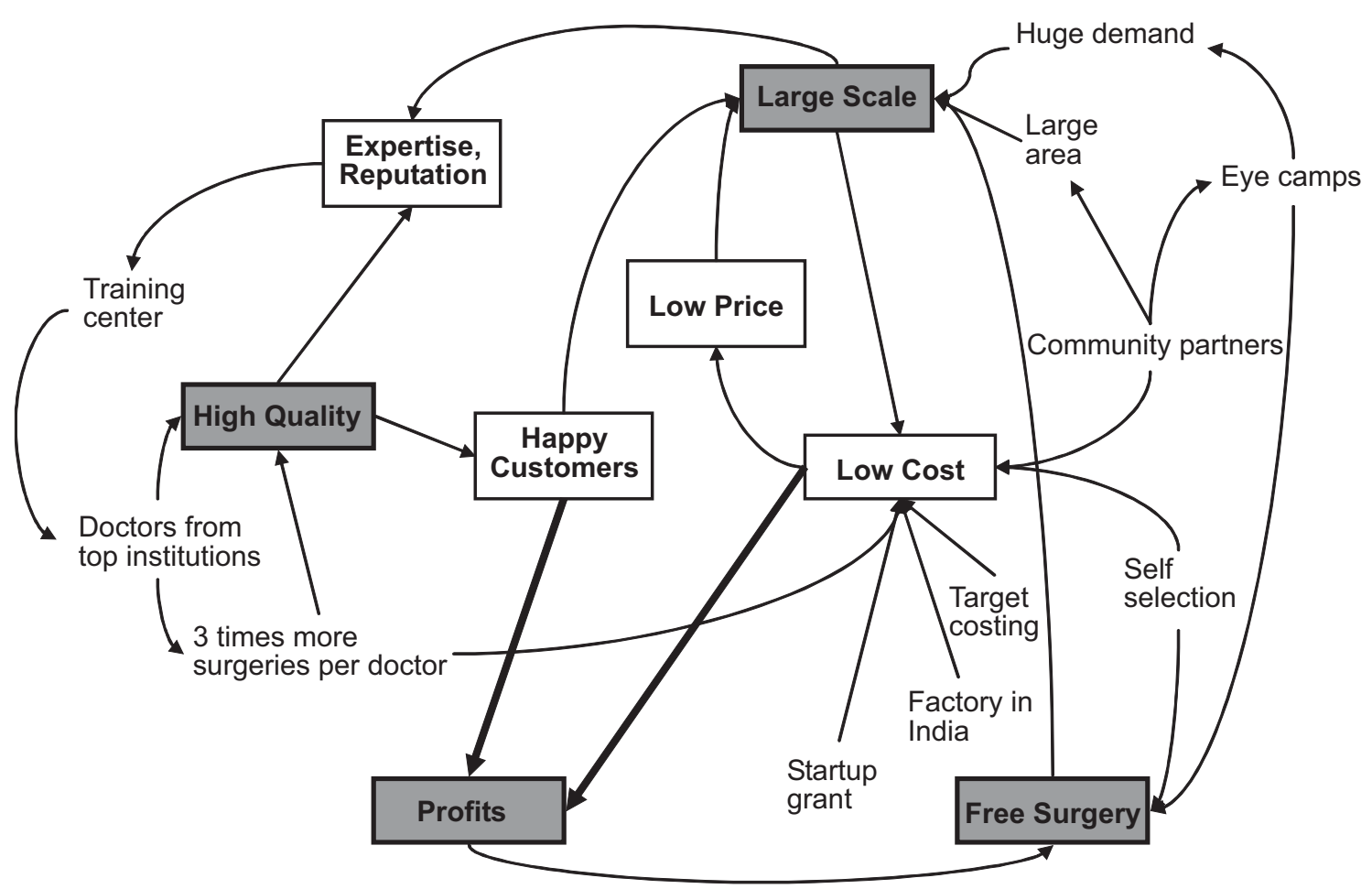

While Aurolab is a non-profit structure, we speculate that an existing lens-manufacturing company might have been able to combine its capital and technical resources and manufacturing capabilities with Aravind's brand and its capabilities in order to orchestrate large-scale, high-productivity eye surgery. Aravind might have agreed to the need for a corporate partner to capture some of the value created for its shareholders given the extent of overall social value created by this model. As David Green said in a recent speech to MBA students, "I am waiting for companies to compete with me or put me out of business for the benefit of the poor".

\section{Collaborative business models to serve underdeveloped markets}

In all three cases, distinct and operationally separate organizational structures aiming to maximize either economic or direct social strategic objectives have cooperated to form an overall business model. GrameenPhone is managed by experienced Telenor managers and only a few local managers. Its strategic objective is to maximize financial returns which it has done very successfully. GrameenTelecom on the other hand is managed by local employees of the Grameen group. It has a very different strategic objective - to maximize the number of jobs created for the rural poor - and a very different organizational culture and management structure, which is immediately evident from interviews with personnel from both 
organizations. Thus, while GrameenPhone has created about 600 jobs and significant profits, GrameenTelecom has created more than 100,000 jobs but at much lower profits. However, both organizations are very much dependent on each other and each contributes significantly to the other's success. We therefore refer to this model of cooperation between companies and social entrepreneurs as the symbiotic model. It is a business model that is built on separate organizational structures with different strategic objectives and different target customers, yet together they build an overall model for social and economic development (Figure 3).

\section{Figure 3}

Organizational structures and strategic objectives of the three business models

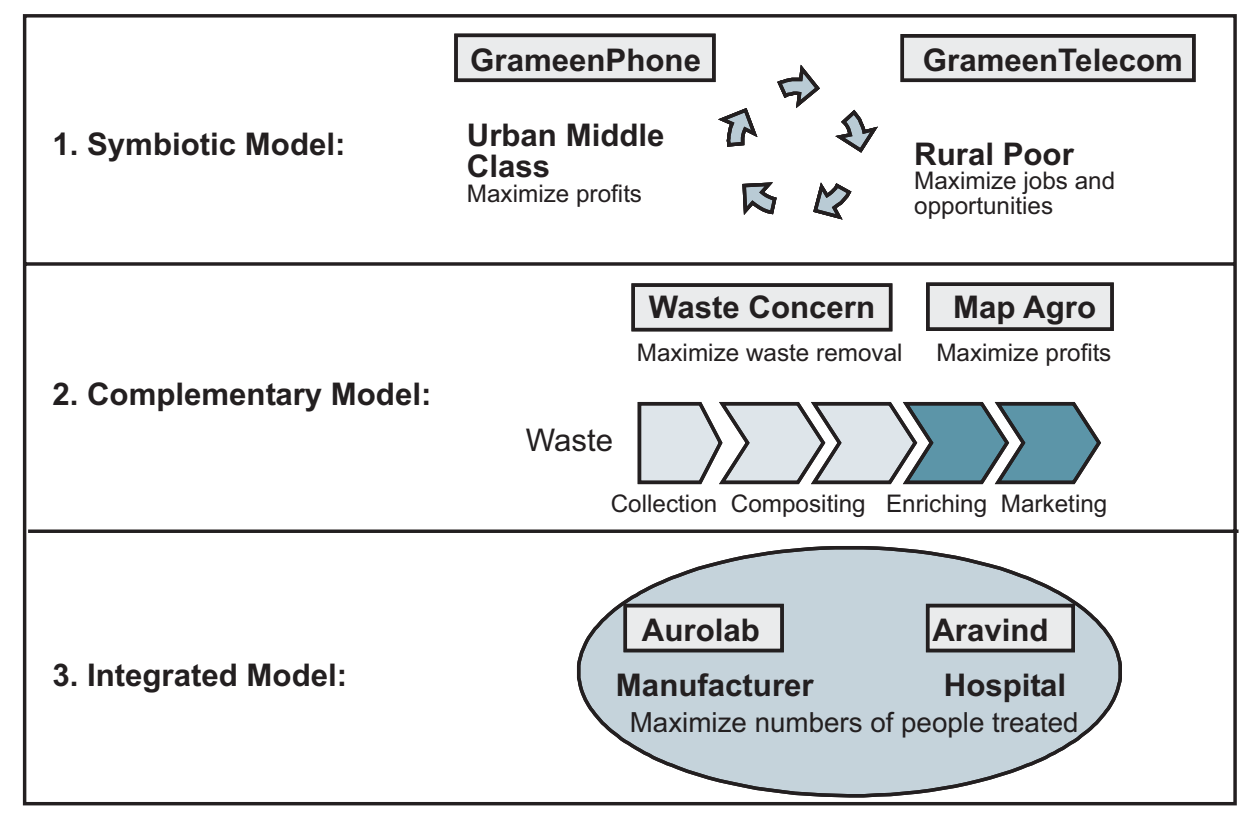

In the case of Waste Concern and Map Agro, both partners enable a different part of the value chain, but together create a new business model that satisfies expectations for both social and economic returns. We call this the complementary model. The organizational structures are managed separately and have different strategic objectives. Because the objectives were highly complementary, the organizations could construe a new value chain that neither of them could have pursued alone.

The first two cases in this paper reflect the ultimate "blue oceans" scenario - new market space where competition is absent (Kim and Mauborgne, 2004). However, these monopoly positions were not sustainable because proof of concept of possible profits attracted competition. What is different in these two models from the traditional view of serving the bottom of the pyramid is that the poor are not primarily seen as customers but are a vital and integral part of the business model. They perform multiple roles, as employees and customers, suppliers, and business partners.

The collaboration between Aurolab and Aravind demonstrates how creating a radically different quality-to-price ratio, coupled with a consistent business model around clear strategic objectives, allows for serving underdeveloped markets effectively and very profitably. This 
makes the case an insightful model for Christensen's low-end disruption theory, where the lowend refers to a radically lower price/quality ratio. Potentially, Aurolab could aggressively penetrate existing markets with its products. To date, its "mere" 10 percent global market share reflects the fact that most of Aurolab's sales are, by intention, still going to Aravind and to a number of charitable organizations to support their missions. We call the joint venture between Aurolab and Aravind the integrated model. Both entities share the same strategic objectives but are structurally separate. This reflects the very different operational objectives of a manufacturing plant and a health service provider. Very different cultures, management and incentive systems are necessary to drive the unique operational objectives of each entity. This is obviously enormously efficient in achieving the shared overall strategic objective of maximizing the total number of people treated.

\section{Recommendations for executive decision making}

With the goal of creating or entering markets in developing countries or learning about competitive threats emerging from those countries, we recommend companies consider the following actions:

1. Study the initiatives of social entrepreneurs and challenge paradigms about povertyrelated problems and solutions.

2. Include social entrepreneurs in your global market analysis to learn about potentially disrupting innovations.

3. Start building relationships with social entrepreneurs in markets or countries that you might consider entering in the future. Understand what makes them tick and build trust and rapport. Learn about local cultures and social structures.

4. Analyze their business models and examine how they are creating resources that could support a joint effort in targeting the large undeveloped customer base in poor countries. Think about what organizational structures would best deliver company goals and the goals of the entrepreneurs.

5. Invest in the most promising initiatives in the form of "social venture capital". They could be maximizing social impact from your capital while you are buying an option that the initiatives you are funding will create strategic resources on which to base new value propositions in your future markets.

We certainly need to study many more examples of collaborative efforts to learn and understand how they can best be structured and managed from a corporate-strategy perspective. Having said this, it remains to be seen to what extent the cases described here are just unique observations or whether these types of collaborations could become a model for companies to build a large-scale market presence that is positively driven by but also positively drives socio-economic development in today's poor countries. 


\section{References}

Abramovitz, M. (1986), "Catching up, forging ahead, and falling behind", Journal of Economic History, 46(2), pp. 385-406.

Barney, J. B. (1995), "Looking inside for competitive advantage", Academy of Management Executive, 9(4), pp. 49-61.

Christensen, C. M. and M. E. Raynor (2003), "The Innovator's Solution: Creating and Sustaining Successful Growth", Boston, MA, Harvard Business School Press.

Hart, S. L. and C. M. Christensen (2002), "The Great Leap", Sloan Management Review, 44(1), pp. 51-56.

Hitt, M. A., M. T. Dacin, E. Levitas, J. L. Arregle and A. Borza (2000), "Partner Selection in Emerging and Developed Market Contexts: Resource-Based and Organizational Learning Perspectives", A cademy of M anagement J ournal, 43(3), pp. 449-467.

Kim, W. C. and R. Mauborgne (2004), "Blue Ocean Strategy", Harvard Business Review, 82(10), pp. 76-84.

London, T. and S. L. Hart (2004), "Reinventing strategies for emerging markets: Beyond the transnational model", J ournal of International Business Studies, 35(5), pp. 350-370.

Mair, J. and E. Cordes (2004), "Project Impact: The affordable hearing aid project", IESE Teaching Case DG 1472-E.

Malaviya, P., A. Singhal and P. Svenkerud (2004), "Telenor in Bangladesh", INSEAD Teaching Case 304-147-1.

North, D. C. (1990), "Institutions, institutional change and economic performance", Cambridge, UK, Cambridge University Press, page 110.

Prahalad, C. K. and A. Hammond (2002), "Serving the world's poor profitably", Harvard Business Review, 80(9), pp. 48-57.

Prahalad, C. K. and S. L. Hart (2002), "The fortune at the bottom of the pyramid", Strategy + Business (26), pp. 54-67.

Seelos, C. and J. Mair (2005a), "Sustainable development, sustainable profit", European Business Forum (20), pp. 49-53.

Seelos, C. and J. Mair (2005b), "Entrepreneurs in service of the poor - Models for business contributions to sustainable development", Business Horizons, 48(3), pp. 241-246.

Tallman, S. B. and K. Fladmoe-Lindquist (2002), "Internationalization, globalization, and capability-based strategy", California Management Review, 45(1), pp. 116-135.

Teece, D. J., G. Pisano and A. Shuen (1997), "Dynamic capabilities and strategic management", Strategic Management J ournal, 18(7), pp. 509-533.

The World Bank, "Health, Nutrition and Population data platform, Population Projections" Accessed A pril 2006. 
Thurner, C., C. Seelos and J. Mair (2006), "Waste Concern", Study, IESE Business School, Barcelona.

Wright, M., I. Filatotchev, R. E. Hoskisson and M. Peng (2005), "Strategy research in emerging economies: Challenging the conventional wisdom", J ournal of Management Studies, 42(1), pp. 1-33. 